\title{
Experiência docente e desafios extremos: aproximações entre experiência de si e tempos de desilusão
}

\author{
André Marcio Picanço Favacho ${ }^{1}$ \\ amfavacho@hotmail.com
}

\begin{abstract}
Resumo
A experiência docente tem sido tratada a partir dos estudos sobre os saberes práticos do professor. Em razão disso, vários desses estudos atestam que os saberes da docência podem ser classificados em saberes de professores novatos, experientes e de aposentados; e, ainda, saberes da formação inicial, da formação continuada, curriculares, pedagógicos, experienciais etc. $\mathrm{O}$ presente artigo pretende mostrar algumas lacunas sobre esse debate principalmente em função da exclusão de autores que discutiram a experiência propriamente dita. É por esse motivo que o texto retoma alguns estudos de Benjamim e Foucault sobre o tema a fim de problematizar a noção atual de experiência docente. Porém, mais do que isso, quer convidar os pesquisadores e os professores a pensarem com mais rigor a relação docência e sociedade contemporânea, posto que é nesse contexto que a experiência necessita ser pensada. Afinal, a experiência é um caminho aberto ao desconhecido.
\end{abstract}

Palavras-chave: experiência de si; experiência docente; desilusão social; Walter Benjamin; Michel Foucault.

1 Professor da Faculdade de Educação da Universidade Federal de Minas Gerais (FAE/ UFMG). Membro do Núcleo de Estudos e Pesquisas sobre Currículo e Culturas e do Núcleo de Estudos e Pesquisas sobre Trabalho Docente, Formação de Professores e Discurso Pedagógico, ambos da FAE/UEMG.



37 
No Brasil e mesmo no exterior, os estudos de maior impacto sobre a experiência docente foram aqueles que a trataram sob a perspectiva do saber prático do professor. Em outras palavras, a prática docente foi tomada, com toda razão, como núcleo capital do universo dessa experiência, marcadamente mais importante que outros possíveis saberes, posto que foi considerada como o filtro que melhor definiu o conjunto dos saberes do professor. Obviamente, ao longo da história da formação de professores, sempre se falou em saberes da experiência docente, mas nunca antes foi dada a eles tal importância. O status máximo que esse enunciado possuía era o de elogio destinado a alguém que detinha muitos anos vividos em sala de aula sob a honraria: "professores de grande experiência".

Porém, desde os anos 1990, os estudos sobre o saber da experiência docente efetivamente ganharam os postos mais importantes dentro das pesquisas sobre formação de professores nos programas de pós-graduação em educação no Brasil. Internacionalmente, os estudos desse campo datam do início dos anos 1980 - como foi o caso dos estudos de Donald Schon, datados de 1983.

Mesmo recente, essa discussão já acumula um número considerável de publicações, além de possuir - nacional e internacionalmente - vários representantes desse debate como, por exemplo, Donald Schon, Kenneth Zeichner, Antônio Nóvoa, Maurice Tardiff, Bernard Charlot, C. Gauthier, Peres Gomes, Phillipe Perrenoud, Gimeno Sacristán, Selma Pimenta, José Therrien, entre outros.

Entretanto, quase no final da década de 2000, observamos um descontentamento em torno dessa discussão. Sugerimos isso não porque ninguém mais a queira ou porque ela não desperte mais o interesse dos pesquisadores - pelo contrário, ainda é um tema de fôlego -, mas porque suas conclusões e análises têm caído num lugar-comum e previsível; sua máxima, aos berros, se repete incansavelmente: “o saber da experiência do professor precisa ser 
valorizado!" Esse é um fato surpreendente, pois como explicar a superficialidade das respostas nesse campo no momento mesmo em que mais se fala em saberes, conhecimentos, informações, experiências criativas, produção de saber, defesa dos saberes, experiências singulares etc.?

Isso se explica, por um lado, porque as discussões sobre a experiência e o saber docente padecem de um didatismo, presente em um considerável número de estudos que se ocuparam em classificar os supostos saberes docentes, classificando-os em saberes de professores novatos, de professores experientes, de professores aposentados; e, ainda, saberes da formação inicial, da formação continuada, curriculares, pedagógicos, experienciais etc. Por outro lado, porque excluíram desse debate importantes pensadores que tratam da noção de experiência propriamente dita. É certo que eles não dão uma verdade final sobre o assunto, mas podem ajudar quanto ao pensamento das entranhas do tempo e do espaço da experiência, da tradição e da sabedoria, da invenção e da genealogia, características que podem melhor localizar a docência nas tramas do passado, do presente e do futuro. Ora, por que retirar desse debate pensadores como Walter Benjamin, Michel Foucault, E. P. Thompson, Victor Turner, Godfrey Lienhardt, entre outros?

É, pois, nessa direção, que o presente texto inclui os "teóricos da experiência" (nome pouco adequado a esses pensadores) no debate sobre experiência docente, especialmente, limitando-se a Benjamim e Foucault. Com isso, convidam-se os educadores a pensarem a experiência docente não mais como um processo tão "racional" ou mesmo "crítico" de classificação da prática do professor, mas como um processo no qual o professor se experimenta na porosidade da atualidade (e do ato), que nada mais é hoje do que a própria sociedade contemporânea. Desconfia-se que seja nesse espaço que a experiência docente necessita ser pensada e essa é a razão pela qual se mencionam as palavras desilusão, desafios extremos e experiência de si no título desse artigo.

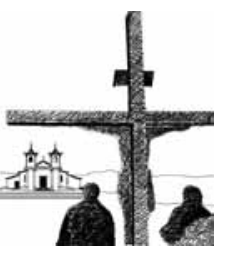




\section{Ajustando os termos}

De inicio, gostaríamos de dizer que a experiência docente será entendida aqui como a maneira pela qual o professor ou professora transforma a si mesmo e o outro diante dos dilemas da vida cotidiana e escolarizada. Esse imperativo contrapõe-se àquele que se ocupa com a classificação dos saberes da docência. Não queremos nos ocupar com os saberes, digamos assim, sociológicos ou psicológicos dos professores, mas com a posição discursiva (histórica e crítica) que os saberes dos professores ocupam na vida cotidiana e na vida escolar.

Já os desafios extremos serão entendidos como todas as demandas sociais atuais que incidem sobre a escola e que requerem dela uma resposta (de preferência imediata), mas que, na realidade, causam muitos transtornos, seja porque tais demandas mexem com a moral dos docentes, seja porque as políticas públicas exigem muito com baixa contrapartida. Demandas como, por exemplo, a inclusão de deficientes, o atendimento às ações afirmativas, a incorporação dos debates sobre gênero, sexualidade e etnia requerem dos professores experiências e formas de deslocamentos bem intensas, nem sempre compensadas ou desejadas. Contudo, não tomaremos esses desafios como empecilhos aos professores, mas como matéria ética própria desse tempo, com a qual o professor produz sua prática.

Com isso queremos dizer que, entre a experiência e os desafios extremos (as demandas), emerge o fato de que hoje não existe apenas o saber cientifico a ser ensinado aos alunos, mas também as próprias demandas da sociedade contemporânea se impõem e necessitam ser discutidas com eles. Tais demandas, por um lado, são incansavelmente exigidas pelas pessoas; por outro, são lentamente pensadas ou refletidas pelos professores; por outro lado ainda, são mal administradas pelo Estado. Entranhar-se nessa discussão requer consentir que entre experiência e demandas há um dilema ético que nos impõe o seguinte impasse: enquanto 
homens e mulheres reivindicam outras formas de viver, a sociedade contemporânea impõe enormes obstáculos - morais, políticos etc - para que se viva de outras formas. É nesse contexto que os professores dizem viver "desafios extremos", pois têm que se esforçar para atender às fortes demandas dos alunos, das famílias e do Estado (além das suas próprias) sem que suas condições de trabalho e formação sejam de fato alteradas para que ao menos compreendam o entorno das tantas exigências.

Partimos do pressuposto, no entanto, de que as desilusões sociais geram desafios extremos, porque marcam um tipo específico de experiência do sujeito contemporâneo cuja sina é o vazio político. Conforme Lipovetsky, o vazio político nos leva a uma falta de discernimento quanto aos destinos da humanidade e isso resulta numa "desagregação da sociedade, dos costumes, do indivíduo contemporâneo da época do consumo de massa, a emergência de um modo de socialização e de individualização inédito" (LIPOVETSKY, 1983, p. 7). Afirma ainda que a partir do século XX, apesar da existência de práticas políticas, econômicas, sociológicas e filosóficas diferentes, o resultado foi essa contínua desagregação que não nos deu alternativa a não ser viver tempos de "privatização alargada, erosão de identidades socais, desafecção ideológica e política" (LIPOVETSKY, 1983, p. 7).

Esse estado de coisas não oferece saídas prontas, pois, conforme relata Ortiz (2007), apesar da desagregação social, a contemporaneidade paradoxalmente produz resultados inimagináveis como, por exemplo, o aparecimento na cena pública de sujeitos assumidos em suas identidades e vontades. De fato, o próprio Lipovetsky alerta para essa forte característica da contemporaneidade: um processo supostamente homogêneo, mas que não ocorre da mesma maneira nem com a mesma intensidade em todos os territórios da vida. No fundo, Lipovetsky e Ortiz mostram a permanente contradição das sociedades contemporâneas de serem ora uma forma de universalizar as particularidades, ora uma forma de relativizar as universalidades.




Benjamin (1994a) também aparece nessa discussão ao constatar que vivemos "tempos de desilusão", referindo-se à artificialidade das relações que a sociedade contemporânea estabeleceu com as coisas, com o mundo e com as pessoas. Porém, em vez de reafirmar como muitos outros o caráter contraditório do contemporâneo, ele mostra sua perversão ou ainda sua galvanização. Ele não crê que essa sociedade seja ora boa ou má, ora necessária ou dispensável e nem crê no dito "pior sem ela"; toda ela estaria recoberta da pretensão de se livrar do humano, de recarregar as energias humanas como se os homens fossem pilhas que, mesmo oxidadas, devessem pôr-se a trabalhar; tudo hoje é de vidro e aço, nada mais respira. Vivemos cansados e não sabemos descansar. E pior: “Ao cansaço segue-se o sonho, e não é raro que o sonho compense a tristeza e o desânimo do dia [...]" (BENJAMIN, 1994a, p. 118). Na desilusão da vida cotidiana, preferimos dormir para sonhar a fim de compensar nossa covardia.

Em termos educacionais, Enguita (2004) traslada as desilusões sociais (ou como ele as denomina de "tempos incertos") para o mal-estar docente, considerando que esse é certamente o resultado do mal-estar social que, com o advento da chamada globalização, teve de atender à nova demanda societal, mercadológica, cientifica e política. Os professores foram atropelados por uma quantidade de outras tarefas e competências que fugiram à tradição de seu ofício. Assim, os professores foram obrigados a produzir respostas a inúmeras demandas, as quais dizem respeito à aprendizagem, formação profissional, informação e comunicação, inclusão, formação de novas consciências ecológicas etc. É óbvio que tudo isso produziu no professor um mal-estar, o que, aliás, possibilitou

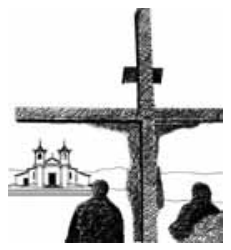
um conjunto de análises sistemáticas sobre tal sofrimento e cujos resultados, entre outros, podem ser observados nas teses sobre o adoecimento do professor, o afastamento do trabalho, a desautorização docente e a desvalorização profissional.

Sendo assim, consideramos que os desafios extremos da docência dizem respeito às mais variadas demandas sociais 
e escolares, não se limitam aos problemas crônicos de um determinado país e se ampliam por toda a contextura global. Porém, só emergem a partir do momento em que essas demandas são problematizadas em espaços específicos. Significa dizer que, embora com algumas características comuns, nem todas as escolas vivem as mesmas demandas. Disso resulta que os desafios extremos não podem ser associados a nenhuma classe social especifica, nem localizados em determinados territórios urbanos (como favelas ou aglomerados), pois são desafios relacionais, estabelecidos em cada realidade; sendo espalhados por todo o tecido social, não se configuram num atributo definitivo de certa classe ou região geográfica. Dessa maneira, tais desafios podem ter sua origem tanto nos problemas sociais como pobreza, desemprego, violência e miséria, quanto em questões de ordem subjetiva/relacional como, por exemplo, a relação de um professor com um aluno deficiente ou com aquele que, apesar de estar na escola há anos, ainda não adquiriu a habilidade da escrita e da leitura.

\section{Sobre a noção de experiência em Benjamin e Foucault}

Em Foucault, podemos dizer que a noção de experiência pode ser vista de três formas: existencial, histórica e ontológica. A experiência existencial, de caráter fenomenológico, se ocupou em "desnaturalizar" a experiência vivida, isto é, cuidou de dizer que ela não era uma essência, um dado natural ou metafísico, e sim uma produção, uma dinâmica social. Contudo, "desnaturalizar" não deve ser confundido com a desmistificação ideológica do tipo marxista que pretende mostrar como um valor exterior foi tomado como seu - imposição de valores de classe sobre outra; a experiência existencial quer "apenas" descrever e interpretar como as pessoas dizem, vivem e expressam, o que vivem e sentem. Ela quer, por assim dizer, revelar os processos subjetivos pelos quais as pessoas passam a fim de dar sentido às suas vidas e ao mundo. Por isso mesmo, ela se permitiu relatar as sensações ou



43 
os diferentes sentidos dados pelos sujeitos às suas experiências, como se quisesse deixar fluir essas experiências subjetivas a ponto de encontrar, ilusoriamente, o momento fundador do sujeito.

O próprio Foucault (1954) parece ter apreciado a experiência existencial. Vê-se, por exemplo, na Introdução (In binswanger, le rêve et l'existence, 1954), que o filosófico defende o autor do livro quando afirma que de fato a única maneira de alcançar o homem está em entender suas formas de existência. Aqui, Foucault quer combater as verdades da psicologia e da filosofia sobre o homem enquanto aposta numa antropologia que, pelo menos em projeto, não separava filosofia e psicologia e, por isso, dava à concepção de homem um tom mais complexo e rigoroso, localizando-o em tempos e espaços próprios. Em outras palavras, a experiência existencial ocupou-se em relatar os sentidos que os sujeitos atribuem a isto ou aquilo, não necessariamente para controlar o dizer, mas para liberar o sujeito para ser o fundador de suas próprias experiências. Nesse tipo de experiência, a análise dos sonhos, da imaginação das pessoas e os processos de significação, segundo Foucault, teriam enorme espaço. Enfim, a experiência existencial queria se apropriar do mundo da vida e fazer com que ele fosse, portanto, a própria "ciência", que narra a vida e escreve a história. Aos elogios de Foucault à experiência existencial seguem suas críticas, sobretudo exigindo dela a sua linguagem; não uma linguagem de signos, mas de formas de existência cuidadosamente construídas pelas vontades. Assim, Foucault se despede da experiência existencial.

Bem diferente, a experiência histórica perde os encantos poéticos e as escrituras nauseantes da anterior. Lastimamos tal perda, mas também reconhecemos seus avanços, pois a mesma coloca a experiência vivida num espaço e tempo mais restritos, retira seu caráter essencialista e se livra de seu aspecto existencialista. Mais preocupada com o caráter representativo da linguagem, essa experiência foge da noção de que a experiência é um processo mental e subjetivo para se dedicar à noção de 
experiência como um processo real, material e visível tanto das formas (in)justas e éticas de viver em sociedade como do simulacro a que a experiência dos homens teve de se sujeitar.

A experiência histórica preferiu encarar as diferentes formas pelas quais os grupos sociais ou classes impuseram suas visões de mundo sobre os outros e como essas visões embaralharamse na cena social, instituindo a vida concreta. Além disso, se interessou em compreender a crise de representação provocada pelos efeitos dessas visões de mundo, que acarretaram a perda de referentes identitários.

A experiência do sujeito, nesse caso, constitui-se como o conflito ideológico entre um referente que não lhe pertence, que lhe é exterior, e um referente que lhe é supostamente adequado (experiência verdadeira), mas que lhe fora roubado. Se o nosso referente verdadeiro foi abalado ou destruído por uma ideologia, como será possível continuar a comunicar nossa experiência? Obviamente, essa experiência parece muito própria da visão marxista, porém, também vemos aí localizado Benjamim - mais do que Foucault -; mais precisamente, vemos Benjamim localizado nos limites da experiência existencial com a experiência histórica.

Ainda que essa afirmação possa ser considerada pura especulação, basta observar que Benjamin, por um lado, fala da experiência como tradição transmitida pelos sábios e necessária à vida, de como ela permite e admite que o sujeito fale, conte suas experiências, recorra à memória para contar tudo que se passou até o ponto do outro saber qual lição tirar para a vida presente. Mas ele também denuncia e culpa, por outro lado, a vida moderna pela morte da tradição e da experiência, pela morte da transmissão e do sábio.

A parte existencial de Benjamim pode muito bem ser atestada em seu texto "O narrador: considerações sobre a obra de Nicolai Leskov, de 1936", que trata da história de um "sábio", na verdade, de um escritor de narrativas de cotidianos religiosos da segunda metade do século XIX. Nesse texto, Benjamim vê em Leskov o fim da arte de narrar própria dos tempos de tradição e de experiência,

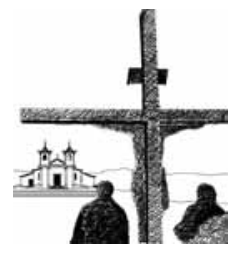


posto que "descrever um Leskov como narrador não significa trazê-lo mais perto de nós, e sim, pelo contrário, aumentar a distância que nos separa dele" (BENJAMIM, 1936, p. 197).

Leskov, que se dedicou às suas viagens comerciais, escreveu várias narrativas de seu tempo como, por exemplo, sobre a classe operária, o alcoolismo, os médicos da polícia, os vendedores desempregados, as quais anunciavam a insuficiência do mundo econômico. Benjamim considera que a experiência narrada por Leskov é o próprio mundo da vida, regada pela matéria da tradição que é a vida por excelência; é tradição e vida na medida em que se torna um excesso de sentido e de sabedoria da qual o sábio se nutre e divulga o saber. Assim, a experiência verdadeira em Benjamin é arte de narrar, contar, transmitir. O sábio, homem experiente, narra sua experiência e com isso aconselha os mais jovens, ajuda-os a resolver os problemas reais do presente com os contos do passado. Aliás, o passado aqui não é um tempo esquecido, e sim um tempo presente, vivido, pois o narrador acrescenta-lhes suas marcas, sua arbitrariedade irredutível, sua autoridade. Dá-se conta, portanto, de que a narração não é simplesmente um contar o que se passou - como num relatório técnico que se entrega a um chefe -, mas um envolver-se totalmente - assim como o artesão - com sua arte, com a coisa narrada, fabricada. Para Benjamin, a narrativa, que durante tanto tempo floresceu num meio artesão - no campo, no mar e na cidade -, é ela própria, num certo sentido, uma forma artesanal de comunicação. Assim se imprime na narrativa a marca do narrador, como a mão do oleiro na argila do vaso (BENJAMIN, 1994b, p. 205).

A experiência é a narração da complexidade, extraída dos limites entre a tradição, a sabedoria e a memória. Se não há o que transmitir, não há experiência. Se não há sábios, não há tradição nem memória.

Ora, é exatamente isso que defendeu Benjamin (1994a) em seu texto "Experiência e pobreza", de 1933. É aí que vemos sua cadeira cativa, agora, na experiência histórica, ao julgar que a modernidade é marcada pela incapacidade de transmitir ou de 
comunicar as experiências coletivas, sendo impossível vivermos e comemorarmos juntos as experiências dos velhos, dos sábios e dos provérbios. Depois da Primeira Guerra Mundial, segundo Benjamin, "os combatentes voltaram silenciosos do campo de batalhas" (BENJAMIN, 1994a, p. 115), isto é, morria o valor central da experiência, que é a sua capacidade de narração e transmissão. Os livros de guerra não continham experiências transmissíveis de boca em boca, porque em seu lugar surgira a experiência monstruosa da técnica que sobrepujava o homem. Pereira (2006) esclarece que Benjamim vê no indivíduo moderno um ser pobre de experiência, um ser mudo e silencioso. "É alguém que nada tem a contar, pois nenhuma experiência possui" (PEREIRA, 2006, p. 65). Sua experiência não passa de vivência marcada pelo individualismo, portanto incomunicável, posto que dispensa ou mesmo não deseja o coletivo.

Quando se diz que a contemporaneidade ou a época moderna é marcada pela pluralidade de acontecimentos e por formas ambíguas de estar no mundo (e de fato parece ser), Benjamim torna-se impaciente com essa interpretação e justifica-se dizendo que em especial após a Primeira Guerra Mundial, os homens se desiludiram com mundo, porém, não se tornaram plurais, e sim desesperançosos, talvez desesperados com o que viram. $\mathrm{Na}$ verdade, afirma que os soldados da guerra nos confirmaram até aonde tais acontecimentos nos levam "quando a experiência nos é subtraída, hipócrita ou sorrateiramente, que é hoje uma prova de honradez confessar nossa pobreza" (BENJAMIN, 1994a, p. 115).

Para Benjamin, o resultado disso tudo não é apenas a desagregação da sociedade ou novas formas de subjetividade como querem alguns, mas o nascimento de uma nova barbárie, sendo bárbaro aquele que "contenta-se com pouco, a construir com pouco, sem olhar nem para a direita nem para a esquerda" (BENJAMIN, 1994a, p. 16). Em Benjamin, não há, na sociedade de hoje, negatividade e positividade simultâneas; o que há é uma "desilusão radical". Também não há um ponto positivo e outro




negativo sobre esse assunto, nem, talvez, uma dialética entre esses pontos, pois o que está em jogo é o nascimento de outra sociedade (a contemporânea) ou de criaturas totalmente novas. Criaturas que decidiram experimentar ou rejeitar o homem tradicional enquanto tornam-se o "contemporâneo nu, deitado como um recém-nascido nas fraldas sujas de nossa época" (BENJAMIN, 1994a, p. 116). Satirizando, o autor lembra que vivemos em tempos em que recusamos qualquer semelhança com o humano. Os russos, por exemplo, dão a seus filhos nomes desumanizados, "como Outubro, aludindo à Revolução, ou Pjatileka, aludindo ao Plano Quinquenal, ou Aviachim, aludindo a uma companhia de aviação" (BENJAMIN, 1994a, p. 117).

Mas, afinal, como produzir experiências nessa pobreza de experiência? E, em tempo, perguntamos: há experiências que são pobres e experiências que são ricas? Não! O próprio Benjamin (1994a), pausadamente, nos responde:

Pobreza de experiência: não se deve imaginar que os homens aspirem a novas experiências. Não, eles aspiram a libertar-se de toda experiência, aspiram a um mundo em que possam ostentar tão pura e tão claramente sua pobreza externa e interna, que algo de decente possa resultar disso. Nem sempre eles são ignorantes ou inexperientes. Muitas vezes, podemos afirmar o oposto: eles "devoraram" tudo, a "cultura" e os "homens", e ficaram saciados e exaustos. "Vocês estão todos cansados - e tudo porque não concentraram todos os seus pensamentos num plano totalmente simples mas absolutamente grandioso" (BENJAMIN,

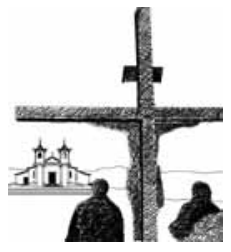
1994a, p. 118).

De fato, a experiência histórica de Benjamin é implacável não somente porque nos "ofende" frontalmente, mas porque nos mostra o quanto somos cínicos e pretensiosos diante da sabedoria e da tradição; mesmo cansados e exaustos, embrutecidos e ignorantes, ostentamos um saber vazio. A morte, no corpo 48

Ano 13 - n. 15 - julho 2010 - p. 37-60 
desfalecido do outro, é o troféu que recompensa o embotamento de nossas verdades. Das guerras cotidianas, voltamos cansados sim, mas vaidosos por termos matado nossos inimigos. A despeito do valor da tradição, a guerra cotidiana consome o homem - como medida de todas as coisas - enquanto institui o poder tecnológico da informação e da comunicação. Diríamos que, com a guerra, o homem foi, no fundo, substituído pelos "ciborgs", esses seres mistos (homem e máquina) que preveem as estratégias de guerra à revelia dos homens.

O Leskov de Benjamin parece ser um bom exemplo de significação que perdeu seu lugar para os ciborges, isto é, um típico personagem fundador de um saber, cuja autoridade residia exatamente em dizer a verdade de que o outro necessitava e que, com o advento da modernidade, foi morto, banido da cena pública e exilado nos confins da memória. Em seu lugar, aparece o ciborg - essa figura escrota e sem escrúpulos -, programado para repetir os padrões de qualidade.

O melhor de Benjamin para a análise da experiência docente é que não precisamos imaginar as mazelas e as fraquezas de espírito do nosso antigo professor primário. Não precisamos saber de sua intimidade, posto que o que deve interessar é sua sabedoria. No máximo devemos tê-lo em altíssimo respeito para que seu mundo sagrado seja preservado. Porém, o melhor mesmo de Benjamin é poder, hoje, desconfiar de todos nós, pois, sem exceção, estamos todos atolados "até a tampa" nas fraudas sujas da contemporaneidade. Somos, independente da idade, assassinos da tradição e da sabedoria; somos os novos bárbaros: estamos todos cansados de tanta soberba. A propósito, quando na história docente, matamos a sabedoria do professor? Quem seria capaz de dizer, afinal, quais são ou seriam as sabedorias da docência? Se a experiência de Benjamin é esse excesso positivo de sentido, desejoso de ser transmitido ou comunicado porque tem muito a dizer, que tipo de experiência docente gostaríamos de transmitir ou estamos transmitindo aos que acabaram de chegar em nossas

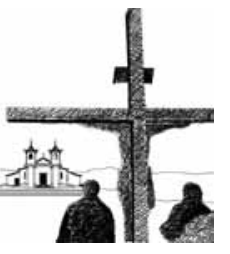


salas de aula e na própria profissão?

Então, a pergunta que devemos fazer não é mais simplesmente sobre o que são as desilusões sociais ou se existem experiências ricas ou pobres, mas sim qual é a relação estabelecida entre experiência e história; entre experiência e o tempo presente; entre práticas e formas de constituição do "eu", entre prática social e o sujeito que nela atua. E, no caso deste artigo, vale perguntar: o que é experiência docente em tempos de pobreza de experiência? Como ela se constituiu ou resistiu a tudo isso nos últimos tempos? Qual a relação entre os acontecimentos de nossa história e a produção da experiência escolar? Basta dizer que a experiência docente vive os mesmos problemas dos tempos incertos ou teremos que acompanhar sua instituição?

Por fim, chegamos à terceira experiência, a ontológica. É nela que situamos Foucault. Tal ontologia nada tem a ver com verdades metafísicas e descontextualizadas. Longe disso, ela é a implicação possível do sujeito com a escrita de sua própria história e a de todos. Por isso, é também uma experiência histórica, mas também de si. É histórica sim, mas não se restringe a narrar o que o sujeito diz, nem a imaginar suas construções subjetivas. Sem desprezar os contextos, a experiência ontológica ou de si ocupa em saber se é possível estudar as diferentes experiências das pessoas, constituindo três aspectos da humanidade moderna, a saber: o homem como sujeito do conhecimento, como sujeito social e jurídico e como sujeito ético.

Em outras palavras, a experiência ontológica não se ocupa com as sensações ou significações do homem, nem se sua experiência decorre da forma como a sociedade se impôs sobre ele, mas necessariamente de como os sujeitos ocupam (desejam e resistem) a seus lugares no jogo da verdade, nas relações de poder e nas formas de se relacionar consigo mesmo e com os outros. A modernidade, por exemplo, para Foucault (1984), não é apenas um período temporal da história, e sim uma atitude - "atitude de modernidade". Para ele, é uma experiência ontológica, ou seja, um 
comportamento, uma forma de pensar, uma espécie de ethos grego, segundo a qual o sujeito só ascende à verdade pelo conhecimento. O conhecimento, só ele, oferece as condições sob as quais o sujeito tem acesso à verdade. Foucault não crê nisso, mas afirma que foi exatamente isso que nos permitiu entrar na era moderna. Quem está fora disso? Quem está contra isso?

Asseguremo-nos, então, da máxima foucaultiana: a experiência é sempre experiência de si, daí porque ontológica, mas também histórica (por isso mesmo crítica), isto é,

deve ser considerada não certamente como uma teoria, uma doutrina, nem mesmo como um corpo permanente de saber que se acumula; é preciso concebê-la como uma atitude, um ethos, uma vida filosófica em que a crítica do que somos é simultaneamente análise histórica dos limites que nos são colocados e prova de sua ultrapassagem possível (FOUCAULT, 1984, p. 351).

Embora seja assim, nem sempre Foucault entendeu a experiência nesse lugar. Ele mesmo fala que inicialmente sua noção de experiência estava bem mais próxima das experiências de significação tanto existencialistas como históricas; achava que o papel do intelectual era talvez descobrir as significações originárias do sujeito diante de suas práticas, como se o sujeito fosse dono do que faz e detém ou controlador do seu fazer, podendo, se quisesse, até se desalienar.

De fato, Foucault (1978) declara que a sua formação filosófica universitária o levava para esse lugar, uma vez que nela dominaram a filosofia de Hegel e da fenomenologia. Mas era chegada a hora de se decidir a não ser um historiador da filosofia, nem um existencialista. Segundo o filósofo, aproximar-se dos escritos de Nietzsche, Bataille e Blanchot foi decisivo para que ele vislumbrasse outro tipo de experiência (a da dessubjetivação), que era ao mesmo tempo crítica e engajada, mas também "anárquica"; além de crítica, visava retirar do sujeito o impossível ou a intensidade mais enérgica possível do lugar que ocupava na cena pública.

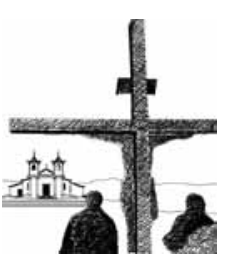

51 
Mesmo assim, Foucault preferiu ainda buscar uma experiência que fosse menos heróica, revolucionária ou ruidosa e concomitantemente mais desconcertante, provocativa e irônica. Uma experiência que mostrasse o caráter epistemológico e político das práticas das pessoas - é o caso dos estudos sobre o nascimento das ciências humanas e dos governos -, mas também o trabalho ético que o sujeito destina ao seu próprio corpo, como mostrou nos estudos da história da sexualidade, da hermenêutica do sujeito etc. A experiência, nesse caso, não se ocupou nem tão somente do conhecimento ou da política, mas pelo contrário, interrogou ambos exatamente em sua vontade de poder. Numa perspectiva foucaultiana, a experiência ontológica nasce no momento mesmo em que o sujeito deve aparecer, no momento em que ele decide (ou não) se autoflagelar, se autopunir, se autocontrolar, ou seja, é nesse momento que a experiência ontológica nasce, nas possibilidades de ação do sujeito ao se relacionar com o estabelecido, com o proibido, com o desejado e com o permitido. Em virtude disso, o "si" que aparece junto ao termo experiência é a própria atuação do sujeito diante das verdades (do conhecimento) e das imposições de governo (dos poderes), mas também do governo de si mesmo (trabalho ético).

Portanto, esse "si" não deve ser entendido como algo do campo psicológico, e sim do campo genealógico, inscrito nas relações de saber, de poder e de governo de si, na forma como o indivíduo se transforma em sujeito da verdade, do poder e da ética. $\mathrm{O}$ que está em questão na experiência ontológica é como o sujeito transforma certas experiências num jogo complexo de relações consigo mesmo, com a verdade, com o poder e com os outros.

Se a experiência em Foucault é a forma como o sujeito ocupa seu lugar no jogo da verdade, nas relações de poder e no relacionamento consigo mesmo e com os outros, podemos aqui avaliá-la melhor (apenas de forma especulativa) para o campo da docência.

Do ponto de vista do jogo da verdade ou do "sujeito do conhecimento", a loucura, a morte e o crime foram experiências 
privilegiadas nos seus estudos, os quais visavam saber como essas (nossas) experiências se transformaram em conhecimento. Esses tipos de experiências, que, transformadas em conhecimento, geraram as ciências humanas, Foucault (1961) chamou de "experiência-limite". Trata-se de experiências que expressam a relação entre o ser e os seus limites históricos; entre a dispersão das experiências e a sua estatização; entre a sua estatização e a reação dos sujeitos frente a isso.

Por serem históricas, tais experiências-limite são imediatamente contrapostas por "atitudes-limites", que são as formas de ultrapassagens e de transgressão social. A atitude-limite é o que criticamos em nós mesmos e, por isso, nos reinventamos não necessariamente para um lugar belo e seguro, mas para outra forma de nos constituirmos como sujeitos frente aos limites que a história nos impõe. É nesse sentido que a experiência é sempre uma crítica de nós mesmos a fim de instituir outra história a partir de outros saberes e poderes; é arrancar o sujeito de si mesmo, de forma que ele saia transformado. Ora, quem disse que o louco se enquadrava nessa palavra? Por que depois de certo tempo a loucura não era mais algo total e passou-se a admitir o seu caráter relativo? No caso da docência, podemos, ainda, perguntar: Quais são e como se instituem as experiências-limite docentes e, por conseguinte, como se delimitaram suas atitudes-limites? Como foi que nos impusemos, por exemplo, a experiência de professores-missionários, vocacionados ao magistério, como nos contrapomos a esse tipo de professor e que tipo de professor (novo) construímos? O professor-missionário deixou de existir? Então, o contraponto não foi suficientemente abrangente?

A experiência de si, nesse caso, é a complexidade discursiva diante das formas como nos apropriamos das verdades existentes, como impomos a nós mesmos algo dessas verdades até o limite de nossa crença ou vontade. E é assim que, segundo Foucault, somos convocados a escrever a história e a história de nós mesmos. Aliás, em termos educacionais, que história da docência está sendo

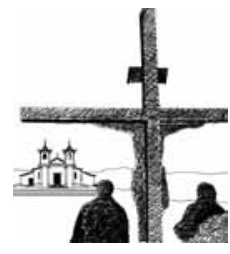


escrita? Que história terá sido escrita para que no futuro as novas gerações possam se orgulhar de nós?

Do ponto de vista das relações de poder, da aceitação das regras ou do rechaço das leis sociais, estudos como "Vigiar e punir" (FOUCAULT, 1975) se constituem em um bom exemplo de experiência jurídica quando esclarecem como o homem se transformou "em sujeito social e jurídico". Nesse caso, já não se trata mais do efeito do conhecimento das ciências humanas sobre os homens, mas, pelo contrário, das disposições do poder sobre seu corpo e/ou as populações, dos quais extraem mais do que conhecimento, saberes e poderes. A experiência é a do homem como sujeito jurídico e social, que aprendeu, nessa trama, a julgar e a se julgar a ponto de saber separar, em seu próprio corpo, o normal do patológico. Com o sujeito social e jurídico, desenhamos a "experiência da normalização", que define quem é o louco, o monstro, o abusador, o delinquente, o mau caráter, o ladrão, enfim, o estranho. A nós, professores, é pertinente perguntar se, na cena educativa, ignoramos essa relação jurídica que define o normal e o anormal. Ou cremos que já superamos essa dicotomia? Somos capazes de transpor com sinceridade esses limites normalizantes? Nasceram novos anormais na atualidade escolar? Essa dicotomia é superável em tão pouco tempo de história?

Por fim, do ponto de vista da relação consigo mesmo e com os outros, os estudos foucaultianos sobre a sexualidade são os mais evidentes de uma experiência ontológica. Ou seja, do ponto vista do "sujeito ético", a sexualidade foi a temática que melhor entrelaçou de uma só vez saber, poder e ética a fim de compreender como os sujeitos se tornaram arbitrariamente sujeitos do desejo.

Nesse caso, Foucault não quer saber o que é o sexo, mas como nos governamos a fim de dizer a verdade sobre nossa sexualidade. Esses estudos são privilegiados no campo ético porque é a parte da experiência ocidental que mais nos convidou a falar, a confessar e dizer a verdade sobre nós mesmos. Refere-se ao sujeito ético, porque em Foucault não se quer saber se alguém julgou as 54 
condutas certas ou erradas, morais ou imorais, mas porque "o próprio individuo se constituiu a si mesmo como um sujeito moral de suas próprias ações" (FOUCAULT, 1984b, p. 28).

A experiência aqui é a do desejo, aquela que define como foi mesmo que chegamos a ser sujeitos de desejo, prontos a dizer a verdade sobre nossa sexualidade. Para além da sexualidade, perguntamos se é certo inferir que a docência, tal qual a sexualidade, também nos tem feito falar, dizer a verdade sobre nós mesmos, nos constituir moralmente como sujeitos do desejo-docência. $\mathrm{Ou}$ seja, o que desejamos em nossa docência? De qual desejo se fala quando se pensa em dar aula: ensinar as pessoas e conduzi-las a algum lugar? Que desejo-docência é esse que nos convida a dizer a verdade sobre nós mesmo e sobre o outro? É possível falar em desejo na docência? Afinal, qual é o desejo da docência, por quais tecnologias ele se compôs no ocidente, qual sua história? Para Foucault (1984b), a ética grega dos prazeres tem a mesma estrutura da política, isto é, trata da questão do governo de si e do outro. Parafraseando-o, provocamos a docência: o desejo-docência não se constituiria na própria política educacional que temos hoje?

Enfim, se Benjamin nos parece um tanto metafísico e trágico; se Foucault nos parece irônico, sem saída e debochado, é que, no fundo, ambos são de uma única e mesma família: "a família dos ferinos". Eles desconfiam de tudo, sobretudo da experiência presente e das formas pelas quais somos capazes - professores ou não - de inventariar nossas práticas morais. Quem será capaz de anunciar, sem constrangimento, as premissas que guiam suas práticas de ensino? Quem será capaz de confessar seu desejo-docência?

\section{Palavras finais}

Mesmo que os tempos de desilusão se caracterizem pelo choque de realidade diante das inumeráveis questões presentes na virada da vida moderna, da artificialidade com que a vida é tratada ou mesmo vivida pela humanidade atual, não é nosso propósito



55 
defender que os desafios extremos são formas de pessimismo ou negativismo, mas sim formas "existenciais" de incômodo que a docência atual enfrenta.

Vemos esses desafios como positividades - não como um valor moral positivo - como atividades (mesmo dispersas, melhor por isso) de lutas (engajadas ou não) para conservar ou alterar os limites próprios do ofício de mestre. Daí porque queremos acreditar que a desilusão social denunciada no projeto filosófico de Benjamim não deve ser entendida apenas como a abolição do homem, mas também - assim como em Foucault - como o lugar no qual os professores se inscrevem ou registram outro espaço de docência, em construção, que por hora se embaça pelo que se nomeia de mal-estar docente.

Ousamos dizer que nós pesquisadores deveríamos nos livrar um pouco das perspectivas do mal-estar e dos didatismos sociológicos em termos de experiência docência e reservá-las para em que fato elas contribuem ao debate da formação de professores: diagnósticos precisos sobre as condições objetivas do trabalho docente. Se essas perspectivas ajudam a localizar as mazelas da experiência docente, elas tendem também a fixar a experiência docente num único lugar: deslocado de seu oficio. Mas se ainda há prazer na docência? É claro que não propomos opor sofrimento e prazer, mas analisar sua relação. Daí porque nossa aposta é a de convidar os pesquisadores a investigar as experiências da docência (e não a do professor/a como individuo isolado em sua sala de aula) em suas múltiplas relações com as verdades, com os poderes e consigo mesmos.

A experiência docente, nesse sentido, não pode ser compreendida por meio apenas de diversas categorizações feitas por um pesquisador da educação para mapear a realidade pesquisada. Mais do que categorizar os saberes, necessitamos responder urgente a uma série de questionamentos, os quais ousamos sugerir aqui: Que experiências extremas temos vivido nas escolas? Que desafios extremos têm exigido o máximo de 
nossa capacidade de indignação? Quais são os desafios que hoje têm sido privilegiados e considerados extremos pelos professores? Que experiências ou saberes nascem diante do enfrentamento (ou não) desses desafios? O que é ou quais são as experiências consideradas relevantes no campo da docência atual, efetivada em tempos de desilusão? A que aspectos das desilusões sociais essas experiências estão relacionadas? Que tipo de experiência docente tem sido considerada válida ou inválida hoje? Que tipo de saber essas experiências convocam (e desencadeiam)? Quais são as experiências-limites que os educadores vivem dentro dos contornos de uma sociedade da informação? Quais são as relações de poder vividas e praticadas pelas experiências docentes? Que tipo de regras escolares elas manifestam? Que tipo de resistência ou de revoltas elas suscitam? Que resultados elas produzem nos alunos e nos próprios professores? Mais ainda: Como o professor ou professora se autoexperimenta diante de classes que não demonstram nenhuma boa-vontade com o mundo escolar? Como esses professores inscrevem em si mesmos as marcas ou traços dessa realidade pouco prazerosa, tendo ainda de buscar saídas para os impasses cotidianos? Afinal, como é estar a contragosto, atuando num cenário que exige grandes responsabilidades sociais e bons resultados finais? Afinal, como é estar contente e cheio de planos mesmo diante desse cenário de pobreza de experiência?

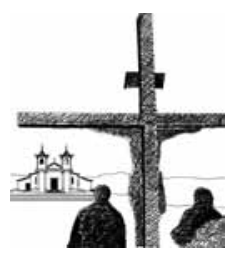




\section{Referências}

BENJAMIN, W. (1933). Experiência e pobreza. In: Magia e técnica, arte e política - ensaios sobre literatura e história da cultura - obras escolhidas. São Paulo: Brasiliense, 1994a.

(1936). O narrador. Considerações sobre a obra de Nikolai Leskov. In: Magia e técnica, arte e política ensaios sobre literatura e história da cultura - obras escolhidas. São Paulo: Brasiliense, 1994b.

ENGUITA, M. Educar em tempos incertos. Porto Alegre: Artmed, 2004.

FOUCAULT, M. (1954). Introdução (in Binswanger). In: MOTA, M. B. da (Org.). Ditos e escritos I - Problematização do sujeito: psicologia, psiquiatria e psicanálise. Rio de Janeiro: Forense Universitária, 2002.

. (1961). Prefácio (Folie et désarison). In: MOTA, M. B. da (Org.). Ditos e escritos I - Problematização do sujeito: psicologia, psiquiatria e psicanálise. Rio de Janeiro: Forense Universitária, 2000.

(1978). Entrettien avec Michel Foucault. In: Dits et ecrits: 1954-1988, v. III (1976-1979). Paris: Galimard, 1994.

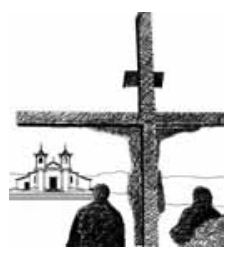

(1984a). O que são as luzes. In: MOTA, M. B. da (Org.). Ditos e escritos II - Arqueologia das ciências e história dos sistemas de pensamento. Org. Manuel Barros da Mota. Rio de Janeiro: Forense Universitária, 2000.

(1984b). História da sexualidade II - o uso dos prazeres.

Rio de Janeiro: Graal, 2003.

58 
LIPOVETSKY. G. A era do vazio: ensaio sobre o individualismo contemporâneo. Lisboa: Relógio d'água, 1983.

ORTIZ, R. Anotações sobre o universal e a diversidade. Revista Brasileira de Educação, Rio de Janeiro, v. 12, n. 34, jan/abr., 2007.

PEREIRA, M. A. Saber do tempo: tradição, experiência e narração em Walter Benjamin. Educação e Realidade, Porto Alegre, 31 (2), p. 61-78, jun./dez. 2006.

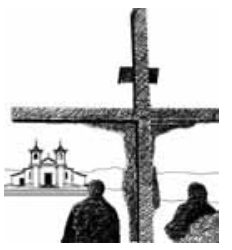




\title{
Teaching experience and challenges extremes: approaches between self experience and experience times of disillusion
}

\begin{abstract}
:
The teaching experience has been treated from the studies on the practical knowledge of the teacher. Because of this, many of these studies show that the knowledge of teaching can be classified into knowledge beginner teachers, experienced and retirees and, still, knowledge of initial training, continuous training, curriculum, educational, experiential, etc. This article aims to show some gaps on this debate, mainly due to the exclusion of authors who discussed the experience itself. That is why it takes a few studies of Benjamin and Foucault on the subject in order to discuss the current notion of teaching experience. But more than that, wants to invite researchers and teachers to think more rigorously the relationship between teaching and contemporary society, since it is in this context that the experience needs to be thought, after all, experience is an open way to the unknown.
\end{abstract}

Keywords: self experience; teaching experience; social disillusion; Walter Benjamin; Michel Foucault.

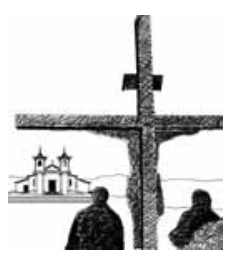

60

Ano 13 - n. 15 - julho 2010 - p. 37-60 